\title{
Isoelectric Focusing Profiles of Pituitary Homogenates of the Japanese Quail during Sexual Maturation
}

\author{
Atsushi Iwasawa, Miho Hoshino, Michiharu Kamiyoshi, \\ Osamu Dor and Takao NAKAmURA \\ Department of Animal Science and Technology, Faculty of Agriculture, \\ Gifu University, Gifu 501-1193, Japan
}

\begin{abstract}
Crude extracts were prepared from the anterior pituitary glands of male and female birds of $8^{-}$and 10-week-old Japanese quails and fractionated by isoelectric focusing. Focused fractions were subjected to a radioreceptor assay using homogenized rat ovary as receptor preparation and ${ }^{125}$ I-labeled rat follicle stimulating hormone as radioligand. This radioreceptor assay was previously characterized for measuring mammalian follicle stimulating hormone. Components having basic isoelectric points (pI) were detected in both male and female birds of 8 - and 10-week old. The component was most basic (pI 12.2) and largest $(1.6 \mu \mathrm{g} /$ fraction/pituitary gland) in 10 -week old female birds. The component in males was larger in 10-week-old birds than in 8 -week-old birds. The present findings suggest that changes in pI and amounts of isoelectric components may be related to sexual maturation in Japanese quails.
\end{abstract}

(Jpn. Poult. Sci., 35 : 189-193, 1998)

Key words : isoelectric focusing, pituitary gland, Japanese quail

\section{Introduction}

Pituitary gonadotropins, luteinizing hormone $(\mathrm{LH})$ and follicle stimulating hormone (FSH) are composed of several molecular isoforms with different isoelectric points, which dissociate into components upon isoelectric focusing (IEF). The IEF fractionation of crude extracts of the pituitary gland has been performed, mainly in mammalian species, to analyze changes in the isoforms under various physiological and experimental conditions (CHAPPel et al., 1982, 1983 ; ROBERTSON et al., 1982 ; WAKABAYASHI, 1977). However, much less information is available concerning the charge heterogeneity of avian pituitary gonadotropins. HATTORI and WAKABAYASHI $(1979,1983)$ reported the presence of isoelectric LH components in the anterior pituitary glands of chickens (Gallus domesticus). They also described differences in the relative amounts of LH isoforms in the pituitary glands between male Japanese quail (Coturnix japonica) kept under long-day and short-day photoperiods (HATTORI and WAKABAYASHI, 1979, 1983). The present study aimed to characterize the pituitary gonadotropin isoforms of both sexes of the Japanese quail at different weeks of age.

Received September 3, 1997 Accepted December 8, 1997 性成熟過程におけるウズラ下垂体抽出物の等電点電気泳動像 岩澤 淳, 星野美保, 上吉道治, 土井 守, 中村孝雄 : 矛501-1193 岐阜市柳戸 1-1 岐阜大学農学 部動物生産学講座 電話 058-293-2873 ファクシミリ 058-293-2840 キーワード : 等電点電気泳動, 下垂体, ウズラ 


\section{Materials and Methods}

Male and female Japanese quail maintained under natural daylight were used from May to July. The birds were killed at 8 and 10 weeks of age. All male birds secreted meringue-like foam from the cloacal gland at these ages. The wet weights of the testes were $1.9 \pm 0.9 \mathrm{~g}$ (mean \pm S.D.) for 8 -week-old males and $3.8 \pm 0.7 \mathrm{~g}$ for 10 -weekold males. Female birds started to lay from 8 weeks old and kept laying in a sequence after 10 weeks of age. The anterior pituitaries ( 20 glands per group) were collected, and immediately frozen on dry ice, and stored at $-80^{\circ} \mathrm{C}$ until use. The glands were homogenized with a glass-glass homogenizer in $100 \mu \mathrm{l}$ of distilled water per gland. The homogenate was centrifuged at $30,000 \times \mathrm{g}$ for $30 \mathrm{~min}$ at $4^{\circ} \mathrm{C}$ after freezing and thawing. The supernatant was subjected to IEF fractionation.

IEF was carried out in a small $(25 \mathrm{~m} l)$ preparative glass column by a modification of the method of TANAKA et al. (1981). Briefly, a linear pH gradient of 3-10.5 was made by mixing carrier ampholites (Pharmalite, Pharmacia Biotech, Tokyo) with $\mathrm{pH}$ ranges of 3-10,4-6.5 and 8-10.5 in a ratio of $6: 1: 3$ at a final dilution of $1: 40$ in a sorbitol solution with a density gradient of $5-50 \%(\mathrm{w} / \mathrm{v})$. The focusing was run at $4{ }^{\circ} \mathrm{C}$ at 300 $\mathrm{V}$ for $18 \mathrm{~h}, 600 \mathrm{~V}$ for $24 \mathrm{~h}$ and $900 \mathrm{~V}$ for $50 \mathrm{~h}$. After focusing, fractions were collected under simultaneous measurement of $\mathrm{pH}$ with a flow-through type $\mathrm{pH}$ electrode. The fractions were adjusted to $\mathrm{pH} 7.0$ with $0.2 \mathrm{M}$ sodium phosphate buffer and stored at $80^{\circ} \mathrm{C}$ until the determination of hormone concentration by radioreceptor assay (RRA).

RRA was carried out according to the method of W AKABAYASHI et al. (1980), using ovarian homogenate of rats primed with pregnant mare serum gonadotropin (PMSG) as receptor source and rat FSH (NIDDK-rFSH-I-8, provided by the National Hormone and Pituitary Program, Rockville, MD, USA) as radioligand and reference preparation.

\section{Results and Discussion}

Large basic components were common in the four pituitary preparations of the Japanese quail, with highest peaks $(1.6 \mu \mathrm{g} /$ fraction/pituitary gland) in 10 -week-old females, second highest in 10-week-old males, third highest in 8-week-old males and lowest in 8-week-old females (Fig. 1). Isoelectric points (pIs) of the peaks were 11.6 (8week-old male), 11.8 (8-week-old female), 11.1 (10-week-old male) and 12.2 (10-week-old female). The basic components contained subsidiary peaks with pI 9.7 in 8 -week-old birds, while they were not distinct in 10-week-old birds.

Pituitary LH of the Japanese quail consists of isoforms having pIs of 9.8, 9.4, 9.0 and 8.5, as revealed by isoelectric focusing of crude homogenates of the quail pituitary gland followed by determinations of the focused fractions by RIA for chicken LH (HAtTori and WaKabayashi, 1979, 1983). Comparing these pIs with the pIs of the components in the present study, we concluded that the large basic components recognized by the RRA were quail $\mathrm{LH}$, although this RRA is specific for FSH, not for LH, in mammals (W AKABAYASHI et al., 1980 ; MinEGISHI et al., 1980, 1982). Since avian LH molecule has some regions similar to those of mammalian FSH, avian LH is recognized as FSH in mammalian FSH receptors (W AKO and IsHI, 1995). This RRA was used in the 


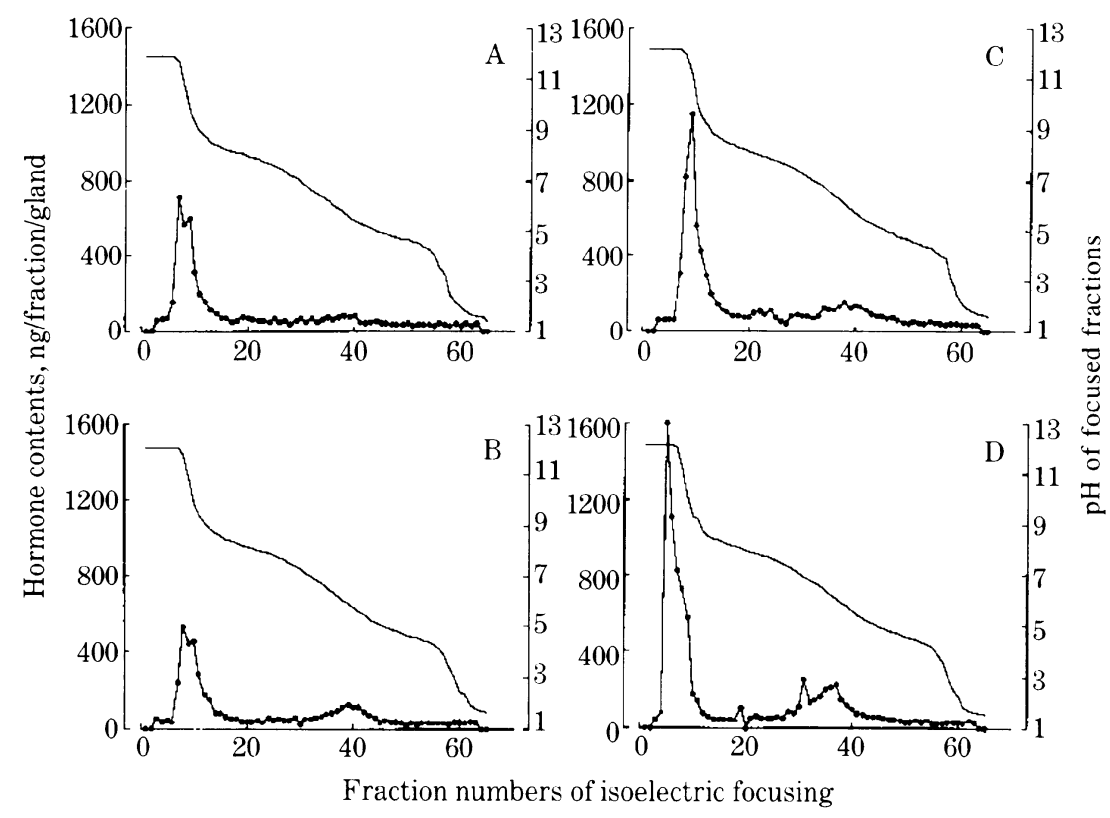

Fig. 1. Isoelectric focusing profiles of the pituitary glands of 8-week-old male (A), 8week-old female (B), 10-week-old male (C) and 10-week-old female (D) Japanese quails. The focused fractions were assayed by a radioreceptor assay using ovarian homogenate of rats as receptor source and ${ }^{125}$ I-labeled rat follicle stimulating hormone as radioligand. Closed circles represent hormone concentrations and solid lines the $\mathrm{pH}$ of the focused fractions.

present experiment in view that it could reflect the biological activity of LH isoforms better than RIA. Furthermore, this RRA is much more sensitive than other RRA methods specific for avian LH (IwASAwa et al., 1995), and hence this method is suitable for analyses of crude homogenate from a small number of avian pituitary glands. The reduced number of $\mathrm{LH}$ isoforms and their more alkaline $\mathrm{pI}$ values in the present study compared with the studies of HATTORI and W AKABAYASHI $(1979,1983)$ are probably due to the $\mathrm{pH}$ range employed, which was $3-10.5$, much wider than the $\mathrm{pH} 7-11$ of their reports.

More basic components of $\mathrm{LH}$ have been found to elicit higher biological activities than more acidic ones using IEF and chromatofocusing studies combined with bioassays and immunoassays in avian (HATTORI and WAKABAYASHI, 1983) as well as in mammalian (Hattori et al., 1983 ; Keel and Grotjan, 1984 ; Lichtenberg et al., 1984) species. Thus, the present result that the pI of the large basic component was altered to a more basic value in 10-week-old female birds in comparison with 8-week-old females, and that the largest peak was in 10-week-old females, seems to reflect the sexual maturation of the birds and is reasonable from the viewpoint of pituitary regulation of ovarian function. The IEF profiles of male birds are also likely to reflect sexual maturation, since the main basic peak was larger and the subsidiary peak with more acidic pI (9.7) was less distinct for 10-week-old males than 8-week-old males. Further focusing studies with narrower $\mathrm{pH}$ range are necessary for detailed analysis of the changes in the large basic components in maturing quail. 
There were in addition, relatively small components with neutral-acidic pIs (7.55.0) in all birds, which were more distinct in females than in males. Reportedly, isoelectric LH components of the Japanese quail pituitary with pIs less than 8.0 are only a trace when assayed by RIA for chicken LH (HATTORI and WAKABAYASHI, 1979, 1983). The present neutral-acidic components are not likely to be FSH, since they are more basic than the reported chicken FSH components (pIs 4.19, 4.39 and 4.75 ; SAKAI and IsHII, 1980). Thus, the significance of the neutral-acidic components of Japanese quail remains to be clarified.

\section{Acknowledgments}

The authors are grateful to Dr. A.F. PArlow and the National Hormone and Pituitary Program for supplying NIDDK immunoreagents, and to Dr. S. IToH of our faculty for providing Japanese quails.

\section{References}

Chappel, S.C., C. Coutifaris and S.J. JacobS (1982) Studies on the microheterogeneity of folliclestimulating hormone present within the anterior pituitary gland of ovariectomized hamsters. Endocrinology, $110: 847-854$.

Chappel, S.C., A. Ulloa-Aguirre and J.A. Ramaley (1983) Sexual maturation in female rats : timerelated changes in the isoelectric focusing pattern of anterior pituitary follicle-stimulating hormone. Biology of Reproduction, $28: 196-205$.

HATTORI, M. and K. WAKABAYASHI (1979) Isoelectric focusing and gel filtration studies on the heterogeneity of avian pituitary luteinizing hormone. General and Comparative Endocrinology, $39: 215-221$.

HatToRi, M., K. SAKAmOto and K. WAKABAyAShi (1983) The presence of LH components having different ratios of bioactivity to immunoreactivity in the rat pituitary glands. Endocrinologia Japonica, 30 : 289-296.

HATTORI, M. and K. WAKABAYASHI (1983) Different profiles of isoelectric avian luteinizing hormone components in biological activity and immunoreactivity. Endocrinologia Japonica, 30 : 551560.

Iwasawa, A., M. Hoshino, Y. Fukuhara, O. Doi, M. Kawashima, M. Kamiyoshi and T. Nakamura (1995) Evaluation of radioreceptor assays for avian gonadotropins. Research Bulletin of the Faculty of Agriculture, Gifu University, No. 60:1-7.

KeEL, B.A. and H.E. GROTJAN, JR. (1984) Characterization of rat lutropin charge microheterogeneity using chromatofocusing. Analytical Biochemistry, $142: 267-270$.

Lichtenberg, V., H.C. Weise, D. Graesslin and G. Bettendorf (1984) Polymorphism of human pituitary luteinizing hormone (LH). Effect of the seven isohormones on mouse Leydig cell functions. FEBS Letters, $169: 21-24$.

MinEgishi, T., M. IgARASHI and K. W AKABAyASHI (1980) Measurement of rat serum FSH by radioreceptor assay and comparison with radioimmunoassay. Endocrinologia Japonica, $27: 717-$ 725 .

Minegishi, T., M. Igarashi and K. Wakabayashi (1982) Measurement of human FSH by radioreceptor assay. Endocrinologia Japonica, $29: 233-240$.

RoBERTSON, D.M., L.M. FouLDS and S. ElLis (1982) Heterogeneity of rat pituitary gonadotropins on electrofocusing ; differences between sexes and after castration. Endocrinology, 111 : 385-391.

SAKAI, H. and S. IsHII (1980) Isolation and characterization of chicken follicle-stimulating hormone. General and Comparative Endocrinology, 42:1-8.

TANAKA, S., H. TAKIKAWA and K. WAKABAYASHI (1981) Seasonal variation in pituitary gonadotropin in the adult male newt, Cynops pyrrhogaster pyrrhogaster, revealed by isoelectric focusing technique and radioreceptor assay. Endocrinologia Japonica, 28 : 335-345. 
W AKABAYASHI, K. (1977) Heterogeneity of rat luteinizing hormone revealed by radioimmunoassay and electrofocusing studies. Endocrinologia Japonica, 24 : 473-485.

WaKABAyAshi, K., T. Minegishi, Y. YorozU, M. IgARASHi and K. IChINOE (1980) A sensitive radioreceptor assay for follicle stimulating hormone with PMS-primed immature rat ovary. Endocrinologia Japonica, $27: 87-93$.

WAKO, H. and S. IsHII (1995) Secondary structure prediction of $\beta$-subunits of the gonadotropinthyrotropin family from its aligned sequences using environment-dependent amino-acid substitution tables and conformational propensities. Biochimica et Biophysica Acta, 1247 : $104-112$. 